\title{
Prompt and safe skin cancer treatment should remain a priority during the pandemic: a rapidly growing basosquamous carcinoma to the tip of the nose in an immunocompromised patient
}

\author{
Agata Marta Plonczak, ${ }^{1}$ Martin Van Carlen, ${ }^{1}$ Natalie Meara, ${ }^{2}$ Aftab Siddiqui ${ }^{1}$
}

${ }^{1}$ Plastic Surgery, Countess of Chester Hospital NHS Foundation Trust, Chester, UK ${ }^{2}$ Histopathology, Countess of Chester Hospital NHS Foundation Trust, Chester, UK

\section{Correspondence to} Agata Marta Plonczak; agata.plonczak@gmail.com

Accepted 2 February 2021
A) Check for updates

(c) BMJ Publishing Group Limited 2021. No commercial re-use. See rights and permissions. Published by BMJ.

To cite: Plonczak AM, Van Carlen M, Meara N, et al. BMJ Case Rep 2021;14:e240539. doi:10.1136/bcr-2020240539

\section{DESCRIPTION}

A 78-year-old patient was referred to us by dermatology with a suspected squamous cell carcinoma (SCC) of the nose.

His risk factors for skin cancer include a myeloproliferative disorder as well as previous SCCs to the right cheek and both ears. His medications include hydroxycarbamide, anagrelide and aspirin. The patient has a background of learning difficulties and lives at home with his nephew, who acted as his carer, as well as his mother. He is able to look after himself with minimal support.

The consultation was remote and the photographs of the lesion to the nose were reviewed by the plastic surgery team. The patient was listed for an urgent excision under the SCC pathway. The lesion was rapidly progressing and transformed from a flat lesion to a $5 \mathrm{~cm}$ raised tumour within a few weeks (figure 1). During the time of COVID-19-related restrictions, the patient underwent excision of the lesion (figure 2) under local anaesthesia within 6 weeks of the consultation in a private hospital used by the National Health Service (NHS) during the time of the pandemic. The measures undertaken to combat the contraction of COVID-19 included preoperative and postoperative patient isolation, preoperative COVID-19 swabs, temperature checks on the day and full personal protective equipment (PPE) for all healthcare professionals.

The histopathology demonstrated basosquamous carcinoma (BSC) of the tip of the nose (figure 3). It

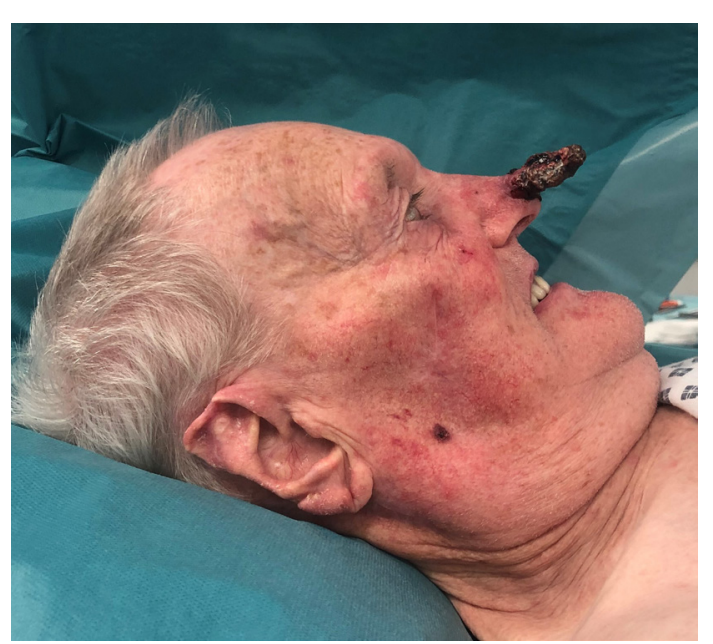

Figure 1 Patient with the tumour to the tip of the nose.

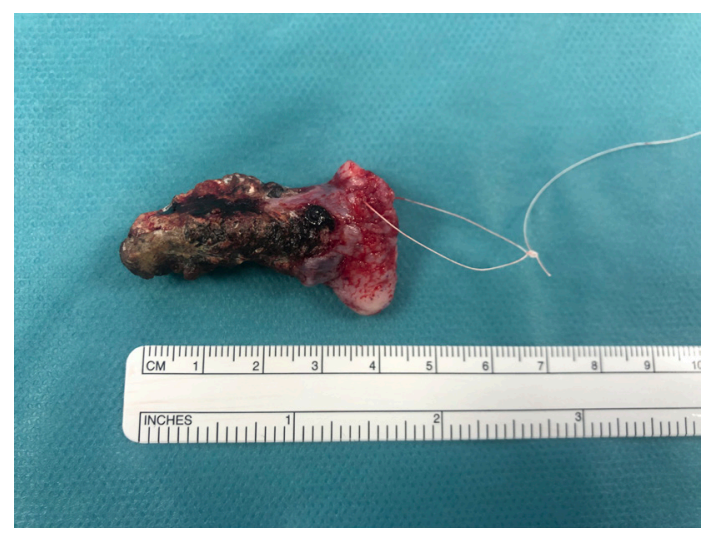

Figure 2 Resected tumour.

was $4 \mathrm{~mm}$ thick with areas of poor differentiation. The plane of excision was down to periosteum. The peripheral margin was $7 \mathrm{~mm}$ and deep margin was $<1 \mathrm{~mm}$. There was no perineural or lymphovascular infiltration.

The patient was subsequently referred for postoperative radiotherapy due to a narrow deep margin. There was no evidence of lymph node involvement or metastases. The patient did not contract COVID-19 due to his skin cancer treatment.

BSC is a rare cutaneous neoplasm with both basaloid and squamous morphology. Its incidence is less than $2 \%$ of all non-melanoma skin cancers. ${ }^{1}$ While

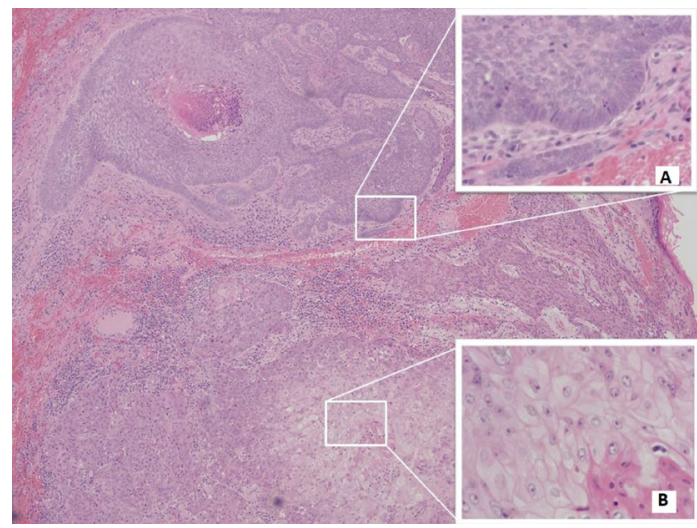

Figure $3 \quad H \& E$ stain. Basosquamous cell carcinoma demonstrating dual morphology; (A) basaloid area with classic peripheral palisade around islands of tumour, (B) second area with squamous differentiation and prominent keratinisation. 


\section{Patient's perspective}

Initially this lesion on my nose started as a little wart. Unfortunately due to COVID-19 my family had to right to get me an appointment. It seemed no-one had time for me due to COVID-19. My niece finally was able to exchange photos with my surgeon; however, due to time lapse I was unable to complete manual tasks such as drinking a cup of tea as the tumour was getting so big I couldn't tip the cup. I ended up going to the hospital and the treatment I received from Mr Siddiqui and his team was perfect. Now that the tumour has been removed I can look at myself in the mirror again. The psychological distress the tumour put on me was massive and the length of time I had to wait did not help this. I want to thank Mr Siddiqui and his team for helping remove this awful tumour from my face.

\section{Learning points}

- Basosquamous carcinoma (BSC) is a rare cutaneous neoplasm with both basaloid and squamous morphology. While histology shows some typical characteristics of basal cell carcinoma, the biological behaviour and aggressiveness of BSC are similar to those of cutaneous squamous cell carcinoma.

- If left untreated BSCs can progress rapidly into very large tumours within weeks.

- Although sometimes regarded as less of an emergency compared with other tumours skin cancer is a huge cause of morbidity and mortality and prompt treatment should remain a priority during the COVID-19 pandemic.

histology shows some typical characteristics of basal cell carcinomas, the biological behaviour and aggressiveness of BSCs are similar to those of cutaneous SCCs. The local recurrence rates of BSCs are as high as $45 \%{ }^{2}$ In addition, BSCs have been reported to metastasise in over $5 \%$ of patients with the condition, rates which are similar to that of SCCs. ${ }^{3}$
While there have been no prospective trials comparing various treatment options, surgical treatments remain the primary treatment of choice for most clinicians. ${ }^{2}$ Though are currently no reports in the literature studying the use of radiotherapy in BSC, its use for incompletely excised tumours remains the treatment of choice. $^{4}$

COVID-19 has had a profound effect on the provision of skin cancer services. ${ }^{5}$ We report a case of a rare BSC which grew rapidly in an immunocompromised patient during lockdown. Although sometimes regarded as less of an emergency compared with other tumours, skin cancer is a huge cause of morbidity and mortality. This case highlights the continuous need for aggressive surgical skin cancer management and it should remain one of the priorities during the pandemic.

Contributors AMP wrote the first draft of the article. MV edited the article and helped to shape the final form of visual material presented. NM edited the article having substantial contribution to the final content. AS is the consultant of the patient who provided clinical care, proposed the idea for the publication and edited the manuscript. All authors approved the final manuscript submitted.

Funding The authors have not declared a specific grant for this research from any funding agency in the public, commercial or not-for-profit sectors.

Competing interests None declared.

Patient consent for publication Obtained.

Provenance and peer review Not commissioned; externally peer reviewed.

\section{REFERENCES}

1 Betti R, Crosti C, Ghiozzi S, et al. Basosquamous cell carcinoma: a survey of 76 patients and a comparative analysis of basal cell carcinomas and squamous cell carcinomas. Eur J Dermatol 2013;23:83-6.

2 Tan CZ, Rieger KE, Sarin KY. Basosquamous Carcinoma: Controversy, Advances, and Future Directions. Dermatol Surg 2017;43:23-31.

3 Wermker K, Roknic N, Goessling K, Klein M, et al. Basosquamous carcinoma of the head and neck: clinical and histologic characteristics and their impact on disease progression. Neoplasia 2015;17:301-5.

4 Oldbury JW, Wain RAJ, Abas S, et al. Basosquamous carcinoma: a single centre clinicopathological evaluation and proposal of an evidence-based protocol. J Skin Cancer 2018;2018:1-7.

5 Nolan GS, Dunne JA, Kiely AL, et al. The effect of the COVID-19 pandemic on skin cancer surgery in the United Kingdom: a national, multi-centre, prospective cohort study and survey of plastic surgeons. Br J Surg 2020;107:e598-e600. Online ahead of print.

Copyright 2021 BMJ Publishing Group. All rights reserved. For permission to reuse any of this content visit

https://www.bmj.com/company/products-services/rights-and-licensing/permissions/

BMJ Case Report Fellows may re-use this article for personal use and teaching without any further permission.

Become a Fellow of BMJ Case Reports today and you can:

- Submit as many cases as you like

- Enjoy fast sympathetic peer review and rapid publication of accepted articles

- Access all the published articles

- Re-use any of the published material for personal use and teaching without further permission

Customer Service

If you have any further queries about your subscription, please contact our customer services team on +44 (0) 2071111105 or via email at support@bmj.com.

Visit casereports.bmj.com for more articles like this and to become a Fellow 